\title{
CREATION OF PAKISTAN
}

\section{Shakila Noor Sindhu}

\author{
Asst. Prof., Forman Christian College University, Pakistan, shakilasindhu@fccollege.edu.pk
}

\begin{abstract}
Creation of a country is not an ordinary situation. But creation of Pakistan is an exception in the world history. This is one of the most debated topics in the subcontinent's socioeconomic, literature, art and political realm. Scores of researchers have investigated this extraordinary historical development in a diversity of perspectives and paradigms. Variety of exogenous and endogenous factors and a range of variables that acted, reacted and interacted among each other are evaluated. Following are the few of the contradicting and contesting narratives that are often used to explain and conclude the division of British India. 1) WWII led to exceptional circumstances that drove British to divide subcontinent. 2) Hindus created Pakistan like Lala Lajpat Rai had proposed the partition in 1920s to keep Hindustan a peaceful land for Hindus. 3)

The unscrupulous attitude of Hindu leadership and the atrocities of the Congress Ministries paved the way of partition. 4) Allama Iqbal's dreams and Ch. Rehmat Ali's "Now or Never" motivated the Muslims of the subcontinent to parting their ways. 5) Pakistan was a creation of the British mind. 6) Pakistan was the result of strenuous efforts of Muhammad Ali Jinnah.

These different scholarships are neither absolute truths, nor an utter deception, but a language of political discourse. This paper will adopt a postmodernist approach to re-search and appraise the above stated hypothesis. This is a qualitative and descriptive research and secondary data is used to carry out this project. Subsequent questions are used in this paper: 1. To explore and investigate both the domestic and international circumstances that led to the creation of Pakistan. 2. To evaluate the role of leadership in dividing British India. 3. To investigate the ideological standings of different actors of the subcontinent
\end{abstract}

Time period and variables: 1935 to 1947 is the time slot selected to evaluate the above stated questions. Based on these questions three variables, i) Events ii) Leadership and iii) Ideology are chosen to carry out this project;

All these variables, events, leadership and ideology were intertwined and contributed in the creation of Pakistan. There was no one point formula that can be made responsible for the division of India. Different factors bestowed for this unique incident in the history. Of course the pressure of marginality and absorption played as a fear factor among the Muslims. But, it goes without saying that Hindus and Muslims were different from each other and the British styled political system fanned these differences and drifted them towards opposite directions. Their cultural, linguistic dissimilarities were stirred up. The same concepts emerged on the political horizon of British India with totally different meanings, like freedom, self-rule, representation, and justice. A long series of events happened both at the national and international level, cultivated a peculiar environment that was nurtured by the leaders of British India and further shaped by the ideology of the participants, eventually divided British India into two sovereign states India and Pakistan.

Keywords: Pakistan, freedom, leadership, ideology, WW-II, communalism, imperialism, colonization 


\section{INTRODUCTION}

Creation of a country is not an ordinary situation. But creation of Pakistan is an exception in the world history. This is one of the most debated topics in the subcontinent's socioeconomic, literature, art and political realm. Scores of researchers have investigated this extraordinary historical development in a diversity of perspectives and paradigms. Variety of exogenous and endogenous factors and a range of variables that acted, reacted and interacted among each other are evaluated. Following are the few of the contradicting and contesting narratives that are often used to explain and conclude the division of British India.

WWII led to exceptional circumstances that drove British to divide subcontinent (Magdoff, 1978, pp. 68-70). Hindus created Pakistan like Lala Lajpat Rai had proposed the partition in 1920s to keep Hindustan a peaceful land for Hindus (Qalb-i-Abid, Abid, 2008, p. 142). The unscrupulous attitude of Hindu leadership and the atrocities of the Congress Ministries paved the way of partition (Jajja, 2012, pp. 302-306). Allama Iqbal's dreams (Chawla, 2008, pp. 91-92) and Ch. Rehmat Ali's now or never motivated the Muslims of the subcontinent to part their ways (Ali, 1933, p. 2). Pakistan was a creation of the British mind (Khan, 1969, pp. 201-238) Pakistan was the result of strenuous efforts of Muhammad Ali Jinnah (Mujahid, 2006, p. 3).

These different scholarships are neither absolute truths, nor an utter deception, but a language of political discourse. This paper will adopt a postmodernist approach to re-search and appraise the above stated hypothesis. This is a qualitative and descriptive research and secondary data is used to carry out this project. The proposal is built upon the selected works of Dr. S. Qalb-i-Abid (1997), Abdul Hamid (1967), V.P Menon (1957), Ayesha Jalal (1994), Khan Abdul Ghafar Khan (1969), B.R. Nanda (2010), Jamil Uddin Ahmad (1964) and Maulana Abul Kalam Azad, (1978). This research will contrast and develop their work to furnish a synthesized politico-cultural approach to understand the conceptual jargon.

\section{PARTITION OF SUBCONTINENT}

This section will explore how the people of Subcontinent who have been living together for centuries in a loose confederation realized they cannot be united anymore. The paper is going to investigate the above stated narratives about the creation of Pakistan on the basis of three variables; Events, Leadership, and Ideology. These variables though distinctive yet are intertwined. They will facilitate the readers to understand the than circumstances and environments that triggered a change in the socio-political and economic profile of South Asia and in the lives of millions of people.

\subsection{Events}

The Roundtable conferences (1930-1933) failed to achieve something concrete. However, upon the recommendations and suggestions made during these conferences, efforts were started to draft a constitution for British India. A constitution named the Government of India Act 1935 was launched and implemented in July 1935. This was comprised of two major parts. Part-I was about the federation structure and part-II was about the provincial autonomy although limited one. Part-I never been implemented in British India. 1935 Act was an attempt to introduce the Western Democratic model in India without compromising on the position of the British (Jalal, 1994, pp. 15-16, /Menon, 1957, pp. 51-52). This on one side made Indian nationals sceptical about the future of British India. But on other side the application of this 'Democratic Model' ruined the liberal pluralistic traditions of Indian politics. However, almost all the western concepts like complete self-rule (Purna Sewraj), freedom or independence, elections and representations etc., went through new interpretations and conclusions in British India. Impressions like communalism, distinct ideologies, and alienation were echoed quite loudly in Hindustan on a regular basis.

The first important event that triggered dozens of other events was elections held in February, March 1937 and formulation of Congress Ministries being a winning party. Congress swept these elections because it was the only organized group in India (Hamid, 1967, p. 215). It was well reached among the masses and financially comfortable. The opposition parties were in bleak conditions in comparison to the Congress in all the terms, including their organizing abilities, financial positions and bonding with the masses. Muslim League in 1935/36 was a party of upper stratum Muslims. This group wanted to serve the cause of general Muslim community as long as it is not affecting their positions in socio-political and economic realms. The party's annual sessions or other functions were organized in an elaborated manner. The big halls, amplified decorations and participation only through invitations kept it aloof from the ground realities. He quotes the example the party was hardly seen during Khilaphat Movement days (1914-1922). This opportunity could have been utilized to make it a mass party or pan-Muslim party in India. But Muslim League missed the boat. Therefore, it could be defined more as a leisure club, but not a political party, forget about national political party of Muslims in British India (Singh, 2009, pp. 221-222). 
When the elections were in the air, 'Muslim League was dead than alive' (Hamid, 1967, p. 216). The Congress to the contrary was in a process of reaching out to the people to strengthen their vote bank by presenting their secular and nationalistic agenda. At the same time it was busy in networking with other political parties and groups, including Jamit-UL-Ulema-I-Hind, The Momin Conference, The Ahrara, the Muslim Unity Board, Muslim League, Khan Abdul Ghafar Khan's Khudai Khidmatgar, and Bhimrao Ramji Ambedkar who was a Dalit leader. They knew Western styled democracy is nothing but counting the numbers. If they alone could not make it, they have to have allies to build a support structure. In order to materialize their success they were not leaving any stone unturned.

The Congress won elections not as it was anticipated, but more than their expectations. This was a turning point in the history. The next step was to form the government and run the state affairs as it normally happens in a democratic process. However, the Congress was in a bargaining mood with the British. Although the party had been agreed to contest elections under the Act of 1935 but now they were not willing to get along with it. The new agenda of the party was to curtail the powers of the Governors (Azad, 1978, pp. 13-15/ zaman, 1985, p. 83). The desire of power accumulation was hampering Congress to take the charge. Although the Muslim League could not emerge as a powerful rival but there was a fairly large group of Muslims who had won elections from other political platforms. The apprehension was that a powerful opposition may restrain congress to follow up its plans. If the conflict between the government and opposition remained unsolved the Governor might use special powers. Therefore, it was important to take pre-emptive measures and receive a guarantee that Governor must not use special powers and responsibilities in either case.

The leaders of Congress wanted to tailor the Act of 1935 according to their desires. For them the Act was an 'inadequate, anti-democratic and anti-national' constitution (Hamid, 1967, p. 216, Zaman, 1985, 82). The party wanted to make sure that Governor would not exercise his special powers and responsibilities during the tenure of Congress. Although the British authorities were upset on this cropped up situation but they wanted to accommodate the winning party. The British government was not willing to give an impression that they had failed to draft a constitution that is acceptable to all the political parties in British India. The secretary of India and the Governor General made regular assurance to the Congress that special powers would not be used against the popularly elected government. The Congress assumed power in July 1937 and served India until the end of 1939. The new objective of the ruling party was 'to wreck the constitution from within'. This was a different face of the Congress. The victory was a point from where British and Congress started changing their positions.

Congress had adopted a different approach towards their pre-elections formal and informal allies. They collaborated with other parties in those provinces where they could not earn majority. However, the provinces where they were in majority they absolutely ignored other groups. Maulana Abdul Kalam Azad wrote in his biography, 'India Wins Freedom', rejecting the cooperation offer from Muslim League in UP was a mistake by Congress. Had they been accepted, Muslim League would have lost its identity (Azad, 1978, pp. 21-66-68). Jawaharlal's decision allowed this week, unorganized and loose group to revitalize itself as a political party. Mr. Jinnah made a practical and effective use of this situation. He motivated, mobilized and transformed the Muslims into one nation. The election of 1936-37 influenced and stirred the variety of dynamics in British India politics. It unveiled the desire of the majority to see India ruled by one political party and the potential of minority to assert its position by uniting itself and keeping its identity.

The working of Congress ministries was a new chapter in the history of British India. Congress introduced Band-e-Mataram as an anthem in its government led provinces and kept insisting to make it a national song. This song was taken from a Bengali novel Anandamatha (Abbey of Bliss) written by a Bengali novelist Bunkim Chander Chatterji in 1882. The recitation of the song was made mandatory before starting the work of government/legislature. It was made compulsory in schools as well. The song was against the religious belief of the Muslims. For example the stanza four says, "Thou art Durga, Lady and Queen, with her hands that strike and her sword of sheen, Thou art Lakshmi lotus throne..." (http://islamicvoice.com/September2006/Controversy/). These words equate the country with goddess Durga and Lakshmi and insist that it should arise and save us. This is exactly opposite the concept of Tuheed (oneness of Allah) in Islam.

Muslim children were forced to follow the Hindu rituals in schools including worshiping Mr. Gandhi's portrait. They were asked to dress up in Hindu manner. Deliberately the music was played before the mosques during the prayer timings. Fakhr-ul-Islam (Islam, 2010, p. 58) explains the situation in following manner. "The Congress flag flew on the public buildings; Bande Mathram (a song from the anti-Muslim Bangali novel, Anandamatha) was made the national anthem; Hindi replaced Urdu; Cow Slater was banned; Muslim representation in the services was reduced; the Wardha system of education which had pronounced 
overtones of Hindu revivalism was sought to be enforced; Gandhi's portrait was worshiped and school text books extolled the virtues of Hindu culture". The instances of victimization against the Muslims are on record. Dr. Abdul Hamid (1967) quotes in his book, 'Muslim Separatism in India', "Dr. Khare, the ex-premier of Central Province revealed in a press interview that his cabinet had vigorously opposed the confirmation as district officer of the only Muslim civilian in the province for no other reason than that he was a Muslim". Shakoor, $(2003$, p. 85) narrates "the execution of beneficent schemes was in the hands of Hindu officials who saw to it that the Muslims did not get their due share in the benefits. Most department and services of the governments were almost entirely manned and officered by the Hindus. The Muslims were gradually squeezed out of key positions".

The government failed to address the concerns and conflicts between the two main stream groups -Muslims and Hindus. Discriminating and oppressive policies made Congress rule unpopular among the minorities. The series of riots kept triggering and deteriorating the social profile of British India. Ayesha Jalal writes that Congress proved incapable to aggregate and validates people's feeling (Jalal, 1994, p. 43). Its inability to represent the plural society and diverse culture worked as a siren call to the minorities in India. Rather the haughty attitude made people feel alienated and annihilated.

The Muslim League under Jinnah's leadership grew as an active political party and a true representative of Muslims. It formed a committee, under the chairmanship of Raja Syed Muhammad Mahdi of Pirpur, to research and documents the workings of Congress. This document is known as "Pirpur Report". Other reports concerning Muslim grievances in Congress ran provinces were A. K. Fazlul Haque's "Muslim sufferings under Congress rule", and "The Shareef Report". All these reports have revealed the level of atrocities Congress government and its allies had put against the Muslims of British India. (Shakoor 2003, p. 85) The circumstances had made the Muslim community conscious about their future. The question was can they survive if Western styled democracy imposed on them and the government is based on injustice and prejudice.

Another important event was the deep involvement of British government in WW-II. The Muslim Ministries of Bengal and Punjab, announced an unconditional support to the British government. However, Muslim League did not come out openly in support of the government's war efforts, but it did not also oppose it. Congress on other hand was willing to negotiate and make it better off opportunity. This behaviour of Congress leadership was disappointing for British Indian government. The natural outgrowth of this development was that government had only one political party to relay upon. This gave an opportunity to both government and the Muslim League leadership to understand and appreciate each other's problems and stances. On an occasion Lord Linlithgow accepted that Congress wants to avail war as an opportunity. $\mathrm{He}$ also acknowledged that Congress has failed to deliver and address the concerns of Muslim (Jalal, 1994, p. 49).

A striking incident took place in the middle of the November 1939 when Congress resigned. The objective was to pressurize the British government for independence of India. But what they could not foresee was that they will lose their bargaining power. Linlithgow's attitude changed towards congress after this event. (Menon 1957, p. 68. 152). He did not need the support of parliamentary government to do something. This was direct rule of viceroy now. The British generally believed that Congress is against fascism and will probably take no move against them, but Congress had given a call for Civil Disobedience. The Congress resignation was a sign of a rift between the British and the Congress leadership.

The Congress's self-ousting from power changed the political scenario. Now the obvious choice for the viceroy was the second leading party (Singh (2009, p. 282). This was important as well. Viceroy was familiar with the past. His hunch was that if he missed out the opportunity to divide these two majored political parties, Congress and Muslim League, they may get together again as they had done during 1857 and Khalaphat Movement and non-cooperation (Ahmad, 1991, pp. 1-19) Movement (1919-1924). This could have added more worries for the Raj. Therefore, it was important to nip the evil in the bud. The clear inclination of the British government towards Muslim leadership influenced the balance of power at national level. Jinnah himself had admitted that Congress resignation had changed his position. He was now considered at par with Gandhi.

Various historians and imperialists and nationalists are of the view that Morley-Minto reforms of 1909 played a decisive role in the future partition of British India (Chester, 2002). These reforms were an opportunity to increase the Indian participation in the political realm. The very idea of separate electorate introduced change in socio-political life of Indians. They found themselves in a new situation, the majority and minority. Politicians make the most of this situation. They played the religious cards without understanding the impact of these cards on the social fiber of British India. Bipsi Sidhwa, Shiv Kumar, Amrita Pretum and many more have discussed this aspect of partition in their works. 
WW II was another decisive event that shaped the future history of the world. It launched and speeded up the process of decolonization. The countries who partook in the war either allies or axis all suffered a lot. Since the war was fought on the European continent and tolled millions of lives. It destroyed infrastructure and ruined businesses. Now the challenges before the participants were to rebuild, restart and restore infrastructure, business and hope. Meeting the targets required stronger commitment, more time, high energy and resource management. Therefore, the first priority was Britain and not the colonies that were already siphoned off and were emerging as haunting liabilities. Pierce (2009) in his article "Decolonization and the collapse of the British Empire" writes that domestic ground realities did not let Britain with any choice except granting India freedom. Tony Judt delineate in his 'Postwar: A History of Europe Since 1945 (2005) that the Japanese desire of building empire was another factor that drove England to revisit its imperialist policies. Japan already had invaded a British colony, Burma now Myanmar in Asia in 1943 and was aggressively knocking out Southeast Asian countries. Given this situation, keeping India as a British colony means inviting a new war. This was absolutely against the national interest of the Britain (Judt, 2005, p. 280).

By considering the limitations of Britain, reviewing the international environment and sensing that India is no more a free ride, Lord Clement Attlee, The Prime Minister of Britain made a speech to the House of Commons in March 15, 1946 "India is today in a state of great tension and this is indeed a critical moment... It is a time emphatically for very definite and clear action... Let us all realize that whatever the difficulties, whatever the divisions may be, there is this underlying demand among all the Indian peoples... Is it any wonder that today she claims - as a nation of $400,000,000$ (4 billion) people that has twice sent her sons to die for freedom - that she should herself have freedom to decide her own destiny? My colleagues are going to India with the intention of using their utmost endeavours to help her to attain that freedom as speedily and fully as possible" (Pierce, 2009) This statement was a clear indication of the British mind. But, we must not forget that it was the only possible choice British could have made in the given situation. This was neither a curtsey to someone, nor a generosity of the colonial master, but an unbreakable obstruction to maintain the status quo.

\subsection{Leadership}

The leadership role is equally important to track the circumstances that led to the creation of Pakistan. Congress Ministries followed some unprecedented traits. After elections Congress had initiated a process of collaboration with other groups and parties. But, this process was instigated only in the provinces where the party was unable to maintain majority. All those provinces where they had earned majority, they totally ignored everyone. Rather claimed that these are undemocratic moves and Congress supports and believes in democracy. Therefore, ideologically they do not believe, they need to have someone in the cabinet that is not from their party. It is like as if the Labour party won elections in England and offer ministries to Conservative party or vice versa (Hamid, 1967, p. 216).

Congress leadership in the post-election era was not willing to collaborate with the Muslim League. Partly because they feel this is against their secular stance. They have people from almost all the religions and sects as members in their party including Muslims. They represent everybody in India. But this was a wrong perception and inappropriate position of the Leadership. They were secular, and nationalist, even before elections. Yet they were doing networking and trying to have maximum groups and parties as their allies. Had they not been comprehended and acknowledged that British India is a plural society and deeply divers, they had not launched any such campaign? This would have been sufficed to satisfy their ego that they are representing people from all walks of life and religions in British India. Congress used 'Mullahs and Green Flags' (Singh, 2009, p. 227) in bye-election. However, the post-election scenario unwrapped a new package of Congress Leadership. The unexpectedly favourable results of the elections change the behaviour of an avowedly nationalist party into an autocratic political organization. It was now not interested in collaborating with Muslim League or any other party but in absorbing them. Gandhi during an interview stated that 'there is only one party in India that can deliver well to the people and that is the Congress and that was the Congress. I will not accept any other party, except Congress and that is the Congress and that was the Congress. I will not accept any other party, except Congress.'

William Roger Louis in 'More Adventure with Britannia: Personalities, Politics and Culture in Britain' (1998) delineates the behaviors of political leadership after 1937 elections. Roger Louis presents the statement of Mr. Nehru 'there are only two forces in India today, British Imperialism and Indian Nationalism as represented by Congress. The rest must line up, and those who are not with are against us' (Moraes, 1956, p. 268). Mr. Jinnah in response to this statement of Mr. Nehru said, there is a third party 'Muslims' (Singh, 2009, p. 233).

In United Province Congress out rightly rejected the cooperation with Muslims and Muslim League in the 
legislature. Muslim League felt the alienation and powerlessness despite being the part of the House. Many questions arose during this period. What is the future of Muslims who are not the part of Congress? If the Congress won majority with the support of Hindus what is the future of the Muslim community? They may not be able to get elected in the first stage. What even if they got elected? What role they can play in the legislature? Sitting in opposition without being effective is of what use in the long run? Congress will ally them only when they need numbers. What even if they are the member of the Hindu majority cabinet in Congress government? Still, they will be in the minority? Will they be ever in parity or majority with this Western style of democracy?

The leadership of Congress party including Patel and later Jawaharlal Nehru had made their mind that collaboration with Muslim League especially with Mohammad Ali Jinnah as its leader is not possible. The party did not include the Muslim League or Muslims in the decision making process. This deepened the communal identities in India. Muslims become conscious as a separate community without any political prospects. This was parting the ways and a step towards independent Pakistan.

The intolerant behaviour of leadership weakened the chances of collaboration. The lack of confidence, insecurities and impatient manners alienated the followers. Things and situations change. The change always brings challenges. Challenges are both the problems and opportunities. They are tests of leadership qualities. How a leader is accomplishing and exploring those challenges and opportunities determines the graph of success. The Congress being a largest and experienced party could have used this opportunity to promote a plural culture and accommodate the concerns of other political parties.

The Muslims had been disenchanted with the Congress party and Congress Leadership. The Muslim League leadership played the situation well. Mohammad Ali Jinnah learned the practical aspect of politics (Menon, 1957, pp. 56-57). He and his Muslim League had participated in elections as idealist group and now they were exposed to the appalling realities. This was an opportunity for them to revisit their strategy and fixed the problems that bared their success and the possible toll they may have to pay if they could not wake up now.

Jinnah not only proved himself a sole spokesman, but also a sole saviour of the Muslims in British India. Viceroy Lord Linlithgow sent a letter to Zetland the secretary of state for India about his meeting with Jinnah. The Viceroy, Linlithgow said, 'I do not frankly see any deep confidence in him, and I suspect that he is one of those political leaders who can play a personal hand, but no other, and whose permanent control on the allegiance of their followers is frequently open to question' (Nanda 2010, p. 234/ Singh, 2009, p. 239). This was 1937 but just a few more years proved that viceroy's judgment was shallow. Things had gone through a tremendous change. Jinnah emerged as the central figure of Muslims at the national level soon.

The history proves that in March 1940; the time of Pakistan Resolution (IPRI, pp. 95-96) Jinnah had an unquestioned support of almost all prominent leaders of Muslim of India. The resolution was a demand for a separate homeland for the Muslim of British India. This was a clear message that Muslims had no trust in Congress and its government. Sikandar Hayat Khan, Premier of Punjab and Fazl-ul-Haq Premier of Bengal who never were in allegiance with Jinnah supported Jinnah unconditionally. A. K. Fazl-ul-Haq was the one who presented this Pakistan Resolution. This was an unexpected move for Viceroy Lord Linlithgow. His reading about Mohammad Ali Jinnah proved erroneous.

This was the time when Congress tried to seek better relations with Muslim League. The same Congress that believed that Muslim league follows medieval concepts and fear complexes. It had failed to realize that nation state was now an outdated approach and the real issues are economic in nature. Shashi Tharoor says once Nehru wrote a letter to his old friend Khaliquzzaman and asked why should I accept it (The Muslim League) as the representatives of Muslims when I know it represents only the handful of Muslims at the top who deliberately seeks refuge in the name of religion to avoid discussing mass problems' (Tharoor, 2003, p. 107). However, now the Congress leadership was analyzing that Jinnah had become a consensus leader of the Muslims. They were willing to explore some options to devise a common strategy to avoid any crisis. However, the situation had become so complex. The communal differences had sharpened. The Congress had lost its legitimacy and popularity among the majority of Muslims especially after Congress ministries experiences.

Muhammad Ali Jinnah 'Unlike the Viceroy and the Congress leadership, Jinnah did not seem to be worried about the threat posed by the aggressive totalitarian powers to democratic nations in Europe and even in India which was a part of the British Empire. Jinnah's speeches and writings in the months immediately preceding the war did not betray any concern at the worsening of the international situation. His eyes were focused on Indian Politics; his one point program was to checkmate the Congress; it was as if the real threat to India and the world did not emanate from Hitler, Mussolini and other fascists but from Gandhi, Nehru and the Congress. Jinnah was perhaps the only important political leader in India who welcomed the outbreak of 
hostilities in Europe. As he recalled later (in 1945): "There was going to be a deal between Mr. Gandhi and Linlithgow. Providence helped us. The war which nobody welcomes proved to be a blessing in disguise' (Nanda, 2010, p. 271)

Lord Louis Mountbatten was another important person who contributed in the partition process. He was "born and bred out-giving, energetic, bold friendly and open'. He was the last Viceroy of British India and a successor of Lord Wavel. Lousy Chester narrates that Mountbatten joined in February 1947. He was entrusted with the task of settling Indian issues. However, he very quickly sensed that rapprochement between the leading parties of India was simply not possible. Although he was given a time frame of June 1948 but he hastened the process and finished the decolonization of India by August 15, 1947.

Earl Mountbatten was the last Viceroy appointed by the British government. He was entrusted with the responsibility of dividing and liberating India. He was welcomed in a spiral of difficult circumstances. British India was blanketed with communal riots, the leading political parties were extremely sceptical about each other, the police and civil servants were losing their control on public. The army was again divided into communal factions. Congress was adamant that it is the only political party of India and representing all sorts of groups in India. The British government should hand over the powers to Congress and grant India freedom from imperialist claws. However, the Muslim League was not ready to accept any solution except the division of British India into two separate states. Britain on the other hand was craving to withdraw from their onerous Indian responsibilities as promptly as possible. But then the challenge was how to materialize the plan?

A boundary commission was formulated in summer 1947 and Cyril Radcliffe was appointed the Chair of this commission (Chester, 2002). Radcliffe reached India on July 8, 1947 and was told that the process of partition has to be finished by August 15, 1947. The man who was appointed to this role was completely blank about the ground realities of India and the geographic sensitivity. He protested, but the top leadership, including Mountbatten, Nehru and Jinnah all remained firm in their decision. So almost all these top leaders were in favour of dividing British India and made some conscious and unconscious efforts to accelerate the division of India.

\subsection{Ideology}

The ethnic and communal conflicts of British India cannot be understood merely with individualism or holism. The systemism only can furnish a case and justify the whole development that ultimately divided India into two sovereign states. The composition, environment and the structure (Bunge, 2000, p.147) together constructed and deconstructed the atmosphere. In other way the plurality of India (composition) that was eclipsed by inequality (environment) and operating under imperialism (structure) could have not allowed India to go for any other option.

Muslims and Hindus had been living in India for centuries. They together had evolved a plural culture and system in India. However, British imperialism decomposed their long practiced milieu. Apparently the Muslim League and the Congress had many similarities. Both the political parties were headed by lawyers and had Muslims in their ranks. They had the same agenda for several years to set India free from British colonial rule. They were together in Lakhnow pact (1916), Khalaphat movement (1919-1922), Sewdeshi movement and Civil Disobedience. However, gradually they emerged as two distinctive forces. The Western style political system culminated and sharpened their dissimilarities. They surfaced with different conceptualization and conclusions on the same issues, for example, freedom of India, self-rule, representation and democracy. The Congress believed, freedom of India is freedom from the British imperialism. Moreover, it wanted to continue with British political system in independent India (Patal, p. 32. 43). Though this system had contrived communalism in India and caused dissatisfaction among the majority of non-Hindu Indians. Nonetheless, those who were opposing this system had fresh memories of the empathy and governance style of Congress (1937 to 1939) (Zaman. 1985, p.89).

Conversely, the Muslim League's leader Mohammad Ali Jinnah was not agreed with these staces of Congress. He was of the view that freedom is not only freedom from British but also freedom of the exploited majority of British India. Purna Swaraj or complete self-rule does not mean the Congress rule in India. The Indian Muslims are a nation, entitled to exercise their right of self-determination and to establish a homeland for them where they could work out their destiny according to their own ideas of Islamic culture and polity. Allama Muhammad lqbal in 1930 favoured the creation of a Muslim India within India. Others such as Rehmat Ali in 1933 advocated the total separation of Muslim India from the rest of India and the creation of new Muslim state (Pakistan).

Differences between the two communities were there otherwise Congress might have not devised a strategy 
to take Ulemas with them or negotiate with Muslim League before elections. Molana Azad might have not reached to a prominent position in Congress and Congress might have not to be worried to launch a program to reach door to door to convince and stimulate Muslim voters to support Congress (Jalal, 1994, p. 42). They initiated this program after elections when they realized that Muslim voters had rejected Muslim candidates with Congress tickets. All these moves on the part of Congress were a clear message that communal diversity was there in British India. Congress might be claiming to represent all but that was not a fact. At that time it did not appear to be formidable; but as events were to show ten years later, it was the beginning of the end of United India.

The composition, environment and structure had changed the course of history in British India. The Muslims had constructed a theoretical paradigm to intellectually legitimize their demand of a separate homeland. The concept of Two Nation Theory (Ahsan, 1996, pp. 254-264) became a force to integrate and transform the energies of Muslims. They furnished their demand of a separate homeland on their religious identity. They are a nation and have the Right of Self Determination. The principal that is accepted internationally.

\section{CONCLUSION}

Hindus and Muslims were and are different from each other. But to be different is not a crime. The whole nature is a beautiful contrast of differences. This is in fact the plurality that is responsible for the symmetry and survival of the Universe. These two communities remained unchanged under Sultanates and Mughals. Even Jalal ud Din Akkbar's Din-e-Elahi policy could not transform them into one nation.

Through centuries the people of India had managed to evolve a culture of pluralism. The question is what had happened from 1857 to 1947 that both the nations reached to a conclusion, they cannot live together anymore? The answer is 'imperialism'. Imperialism was the real disease that siphoning off the wealth, resources and pluralistic culture of India. The beauty of its diversity was plundered and demoralized. Imperialism had weakened the people in the name of contrived democracy, education and religion. Some of the leaders also proved a tool to materialize the big plan of imperialist powers.

This was imperialism that triggered a change in composition, environment and structure of India. This colonial Master's system fanned differences of two groups and managed to drift them towards opposite directions. Their cultural, linguistic dissimilarities were stirred up. The Western system's concepts emerged with totally different meanings and paradigms in British India, like freedom, self-rule, representation, and justice had different connotations before Hindus and Muslims. It built the mistrust and agony among the people for each other. The innocent Indians were made to bear the 'white man's burden' for about a century.

All those countries that emerged from the ashes of subcontinent believe, they have inherited democracy from their ex-colonial masters. But unfortunately they could not understand that democracy the way it was practiced in Britain had never been allowed to exercise in British India. What these countries inherited is poverty, illiteracy, mistrust and hate besides poor infrastructure and crippling institutions. The governments of these countries are spending millions on weapons but not on the well-being of their people. One set of leaders have fought against the imperialist masters, but their successors are following the ex-master's ways. They have further created the reasons to divide themselves. This could be ethnicity, language, religion, race sectarian or gender divide. They are still in a smokescreen where they cannot see, Scotland, and Wales despite all their peculiar characteristics and distinct identities are the part of Britain. Europe since WW-II has never entered into a war against each other. Americans have transformed themselves from heterogeneity to homogeneity. Democracy is integrating these nations and widening the choices of their people. Than what is wrong with our system or behavior? Why it is the other way round in our countries? This debate is leaving us with further questions. Is it the real independence or transformation from colonization to neo-colonization?

\section{REFERENCE LIST}

Ahmad, Jamil-ud-Din. (1967). Muslim Political Movement. Lahore: United Publishers.

Ahsan, Aitzaz. (1997). Indus Saga and the Making of Pakistan. Karachi: Oxford University Press.

Ali, Ch. Rahmat. (1933). Now or Never: Are We to Live or Perish Forever? Cambridge: Pakistan National Movement.

Azad, Maulana Abul Kalam. (1978). India Wins Freedom. Madras: Orient Longman Itd.

Chawla, Mohammad Iqbal. (2008). "Picture of Muslim Politics in India before Wavell's Viceroyalty". Journal of Research Society of Pakistan. Vol. 45, No.1, 75-138.

Chester, Lucy. (2002). "The 1947 Partition- Drawing the Indo Pakistani Boundary". Retrieved from 
http://www.unc.edu/diplomat-bin/amdipl browse.pl?field=date\&value=2002

Fakhr-ul-Islam. (2010). "The Decisive Decade of Freedom Movement (1937-1947)". The Dialogue. Vol. V, No. 1, 51-77.

Hamid, Abdul. (1967). Muslim Separatism in India - A Brief Survey 1858-1947. London: Oxford University Press.

Jajja, Mohammad Ayub. (2012). "The Heart Divided: A Post-Colonial Perspective on Partition". Pakistan Journal of Social Sciences. Vol. 32, No. 2, 297-307.

Jalal, Ayesha. (1994). The Sole Spokesman. Cambridge: Cambridge University Press.

Judt, Tony. (2005). Postwar: A History of Europe since 1945. New York: The Penguin Press.

Khan, Khan Abdul Ghafar. (2004). Aap Beeti (Biography). Lahore: Fiction House Publishers.

Roger, L. W. (2005). Yet More Adventure With Britannia: Personalities, Politics and Culture in Britain. London: Tausir.

Magdoff, Harry. (1978). Imperialism: From the Colonial Age to the Present. New York: Monthly Review Press.

Menon, V.P. (1957). The Transfer of Power in India. New Jersey: Princeton University Press.

Moraes, Frank. (1956). Jawaharlal Nehru: A Biography. New York: Macmillan Publishers.

Mujahid, Sharif-ul-. (2008). Jinnah's Team: The Top Ten. Paper presented in an International Conference, "On Leaders of Pakistan Movement", at National Institute of Historical and Cultural Research, Islamabad, Pakistan.

Nanda, B.R. (2010). Road to Pakistan - The Life and Times of Muhammad Ali Jinnah. New Delhi: Tolstoy House Publishers.

Pierce, David. (2009). "Decolonization and the Collapse of British Empire". Retrieved from http://www.studentpulse.com/articles/5/decolonization-and-the-collapse-of-the-british-empire

Qalb-i-Abid, Dr. S., Massarrat Abid. (2008). "Muslim League, Jinnah and the Hindu Mahasabha: A Study in Speeches and Statements of Quaid-i-Azam". Journal of Research Society of Pakistan. Vol. 45, No.1, 143-217.

Rahman, "A. Faizur. Vande Mataram and the Muslim". Retrieved from: http://islamicvoice.com/September2006/Controversy

Saggi, P. D. (1973). Life and Work of Sardar Vallabhbhai Patel. Bombay: Overseas Publishing House.

Shakoor, Abida. (2003). Congress-Muslim League Tussle 1937-1940: A Critical Analysis. Delhi: Aakar Book Publishers.

Singh, Jaswant. (2009). Jinnah: India, Partition, Independence. New Delhi: Rupa Publications.

Tharoor, Shashi. (2003). Nehru the Invention of India. New York: Arcade Publishing.

Zaman, Waheed-Uz-. (1964). Towards Pakistan. Lahore: United Publishers. 